\title{
Studies on Geochemical and Heavy Mineral Characteristics of Sediments of Gosthani River Estuary
}

\author{
Fatima Rezaye ${ }^{1 *}$, Shivanna ${ }^{1 \#,}$ M. Jagannadha Rao \\ ${ }^{1}$ Department of Marine Geology, Faculty of Science and Technology, Mangalore University, Mangalore, India \\ ${ }^{2}$ Department of Geology, Faculty of Science and Technology, Andhra University, Vishakhapatnam, India \\ Email: *frezaye_cawc@yahoo.com
}

How to cite this paper: Rezaye, F., Shivanna and Rao, M.J. (2018) Studies on Geochemical and Heavy Mineral Characteristics of Sediments of Gosthani River Estuary. Open Journal of Geology, 8, 263-277. https://doi.org/10.4236/ojg.2018.83017

Received: August 19, 2017

Accepted: March 24, 2018

Published: March 27, 2018

Copyright $\odot 2018$ by authors and Scientific Research Publishing Inc. This work is licensed under the Creative Commons Attribution International License (CC BY 4.0).

http://creativecommons.org/licenses/by/4.0/

\begin{abstract}
The present work deals with the geochemical and heavy mineral characteristics studies of sediments of Gosthani river estuary. The aim of study is to determine the provenance, establish the depositional environment and spatial variability of sediment. From the study it is found that the sediment of Gosthani river contains heavy minerals that consist of Rutile, Garnet, Sillimanite, Staurolite, Monazite, Zercon, Pyroxenes, Epidote, Amphiboles and Opaques minerals. The lesser abundant heavy minerals are amphiboles, zircon, monazite, rutile, staurolite, epidote. These heavy minerals indicate that the sediments were essentially derived from metamorphic provenance varying from medium to high grade and partly from crystalline igneous rocks. Well rounded monazites come from Eastern Ghats. This is based on the occurrence of monazite in pegmatite and charnockites of Eastern Ghats. The various characters of rutile and zircon suggest that each of these minerals has a multisource. According to geochemical studies settling of organic matter is highest in areas where deposition of fine grained sediment takes place. The organic carbon is often a good index for deciphering depositional environment.
\end{abstract}

\section{Keywords}

Geochemical Characteristics, Heavy Mineral, Provenance, Estuary, Gosthani River

\section{Introduction}

The word "estuary" is derived from the Latin word aestuarium meaning tidal inlet of the sea, which in itself is derived from the term aestus, meaning tide. There 
have been many definitions proposed to describe an estuary. The most widely accepted definition is: a semi-enclosed coastal body of water, which has a free connection with the open sea, and within sea water is measurably diluted with freshwater derived from land drainage [1]. However, this definition excludes a number of coastal water bodies such as coastal lagoons and brackish seas. A more comprehensive definition of an estuary is a semi-enclosed body of water connected to the sea as far as the tidal limit or the salt intrusion limit and receiving freshwater runoff; however the freshwater inflow may not be perennial, the connection to the sea may be closed for part of the year and tidal influence may be negligible [2]. This definition includes classical estuaries as well as fjords, lagoons, river mouths, and tidal creeks. An estuary is a dynamic ecosystem with a connection with the open sea through which the sea water enters with the rhythm of the tides. The sea water entering the estuary is diluted by the fresh water flowing from rivers and streams. The pattern of dilution varies between different estuaries and depends on the volume of fresh water, the tidal range, and the extent of evaporation of the water in the estuary [3]. An estuary is a partly enclosed coastal body of brackish water with one or more rivers or streams flowing into it, and with a free connection to the open sea [1]. Estuaries form a transition zone between river environments and maritime environments and are subject to both marine influences, such as tides, waves, and the influx of saline water; and riverine influences, such as flows of fresh water and sediment. The inflows of both sea water and fresh water provide high levels of nutrients in both the water column and sediment, making estuaries among the most productive natural habitats in the world [3].

Most existing estuaries were formed during the Holocene epoch by the flooding of river-eroded or glacially scoured valleys when the sea level began to rise about 10,000 - 12,000 years ago [2]. Estuaries are typically classified by their geo-morphological features or by water circulation patterns and can be referred to by many different names, such as bays, harbours, lagoons, inlets, or sounds, although some of these water bodies do not strictly meet the above definition of an estuary and may be fully saline.

The banks of many estuaries are amongst the most heavily populated areas of the world, with about $60 \%$ of the world's population living along estuaries and the coast. As a result, many estuaries are suffering degradation by many factors, including sedimentation from soil erosion from deforestation, overgrazing and other poor farming practices, overfishing, drainage and filling of wetlands, eutrophication due to excessive nutrients from sewage and animal wastes, pollutants including heavy metals, polychlorinated biphenyls, radionuclides and hydrocarbons from sewage inputs and diking or damming for flood control or water diversion [2] [4].

\section{Literature Review}

\subsection{Heavy Mineral}

Pettijohn [5] defined heavy minerals as the minerals of pre-existing rocks, sur- 
viving destruction, mechanical and interstratal solution and possess specific gravity greater than bromoform (sp.gr. 2.89). Heavy minerals are in general volumetrically minor components of sediment. But, they have occupied a key position in the study of sediment provenance and disposal owing to their diversity and often characteristic paragenesis. Heavies are important economic deposits of resistant high specific gravity minerals formed due to long processes of mechanical concentration resulted by weathering, transportation and deposition in suitable locations. Illing [6] observed that each sedimentary unit in a particular basin has a unique assemblage of detrital minerals and he was the first person to stress on the need to study heavy minerals to know the history of sedimentation which is very essential for the exploration of hydrocarbons. According to Folk [7], study of the heavy minerals constitutes a function of five complex variables, viz. differential stability of the source rock, lithology of the source rock, resistance to long continued abrasion and weathering, hydrodynamic conditions of post and pre-deposition and post-depositional changes. According to Van Andel [8], the variability distribution of heavy minerals enables to build up the erosional and tectonic history of basin. The petrography of the source area is directly related to the heavy mineral assemblages. Krynine [9] and Folk [7] utilised the heavy minerals for determination of provenance. According to Pettijohn [10] heavy minerals are also useful in deciphering the composition and tectonic history of provenance. These are also useful in evaluating pre-erosional history as well as digenetic history [11] [12] stated that the heavy mineral suites are affected not only by provenance, but also by the source area weathering, process of transportation, depositional and post-depositional alteration. In addition, a few studies have also tested the utility of ratios of light to heavy minerals to discriminate different depositional environments [13]. The provenance studies based on the elemental analyses were stressed by Hutton [14] and Ramdohr [15]. Besides being provenance indicators, the heavy minerals like ilmmenite, monazite, zircon, sillimanite, garnet etc., are widely used in many industries for several purposes. The importance of heavy minerals as economic resources has been dealt by Woolsely [16] and Kulm [17]. The mechanism of deposition and derivation of heavy minerals and the factors controlling their concentration have been studied by Rubey [18], Rittenhouse [19], Komar [20] and Li [21].

\subsection{Geochemical Studies}

The organic carbon fraction in sediments is important because it serves as a binding site for contaminant metals. The abundance of organic carbon controls many diagenic processes. Normalizing contaminant data by the percentage of organic carbon allows for the distinction of specific anthropogenic sources [22]. Several factors control the accumulation of organic matter in modern sediments i.e. rate of supply of organic matter to the depositional environment and/or rate of preservation [23] [24] [25] [26]. Settling of organic matter is highest in areas where deposition of fine grained sediment takes place. The organic carbon (OC) 
is often a good index for deciphering depositional environment. Its plays a major role in controlling the redox potential of the sediment of source material for petroleum. The amount of organic carbon in marine sediments reflects the supply and preservation of organic materials from marine and terrestrial sources [27] [28]. Accumulation of organic carbon in the sediments in general, depends on production and deposition rate (this includes also decomposition and consumption of organic carbon after deposition), the rate of burial and dilution by clastics, sediment characteristics and texture. The variation in carbonate content in the bulk sediments is mainly due to the shell fragments and tests of organisms, inorganic and organic precipitation, and the supply of carbonate minerals by the rivers. However, the estuarine environment showed a high amount of carbonate content consequent on the abundance of shell fragments of molluscas and other shells with a number of zooplankton tests.

\subsection{Study Area}

Gosthani River is medium sized east flowing river in Andhra Pradesh, India. Originating in the Ananthagiri Hills of Eastern Ghats, it runs for a distance of $120 \mathrm{~km}$ and debouches into Bay of Bengal at Bheemunipatnam, forming an estuary (lat. $17^{\circ} 53^{\prime}-17^{\circ} 56^{\prime} \mathrm{N}$ : Long $83^{\circ} 26^{\prime}-83^{\circ} 28^{\prime} \mathrm{E}$ ) [29]. The coast is marked by narrow beach and bordered by eastern Ghat hills composed of khondalites, charnockites and granite gneisses. Geomorphologically these hill ranges are perpendicular to the coast, resulting in rocky beaches at places. The depth in the deepest portion of the river is variable from place to place. It is 2 meter in the inlet area at the low tide, $1-1.5$ meters in the back waters and $1.5-2$ meters in the middle section of the river. Knowledge of the textural characteristics of the estuarine sediments is of great importance in differentiating various depositional micro environments [29]. This river is thought to have provided the inhabitants with drinking water and the estuary at Bhimli facilitated sea-borne trade [30] [31].

This area is enclosed between latitudes. $17^{\circ} 53^{\prime}-17^{\circ} 56^{\prime} \mathrm{N}$ and Longitudes $83^{\circ} 26^{\prime}-83^{\circ} 28^{\prime}$ E covering an area of 1255.5 sq. Km (Figure 1 ).

Geologically, the area under study is occupied by $96 \%$ khondalite group of rocks. The area is well represented by structural hills, denudation hills, buried pediment, valley plains forming soil covers of silty clay, red sandy and red loamy and alluvium.

\section{Materials and Methods}

\subsection{Sampling}

Sampling of estuary was carried out using a hand auger. Samples were collected at 6 stations covering the entire mouth of the estuary, paleo channel, and flood plain. At each station 3 to 5 samples have been collected (Photo 1 ). A total of 17 surface and 9 subsurface sediment samples were collected. The samples weight about $1 \mathrm{~kg}$ of sediments was collected from each sampling sites; samples were 


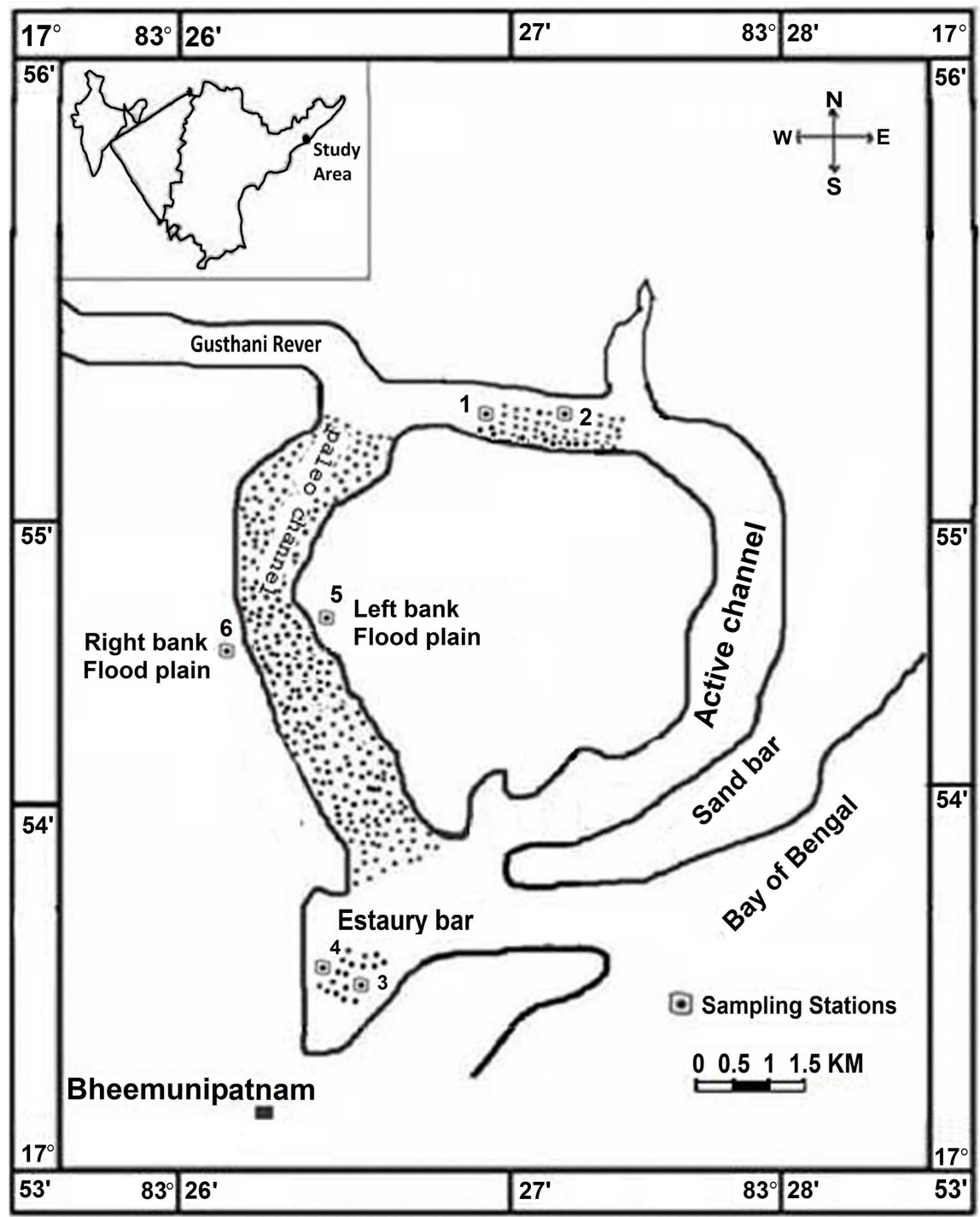

Figure 1. Location map of study area.

stored in sealed bags. The sample location were identified and recorded with the help of GPS. The sample stations are shown in (Figure 1).

\subsection{Method of Study}

\section{Heavy Mineral}

The following procedure has been adopted for heavy mineral analysis. The samples were thoroughly washed through an ASTM 230 mesh sieve with water to remove clay and silt material. The washed samples were treated with a few $\mathrm{ml}$ of dilute hydrochloric acid to remove any carbonate shell fragments and ferruginous coating on the grains. Addition of small amount of stannous chloride accelerates the removal of iron coating. Then the samples were dried and sieved into three ASTM size fraction $+230(-0.125$ to $+0.063 \mathrm{~mm})$. Heavy minerals from the sand fractions have been separated using bromoform (sp.gr.2.89) following the procedure outlined by Krumbein and Pettijohn [32]. The heavy and light fractions 


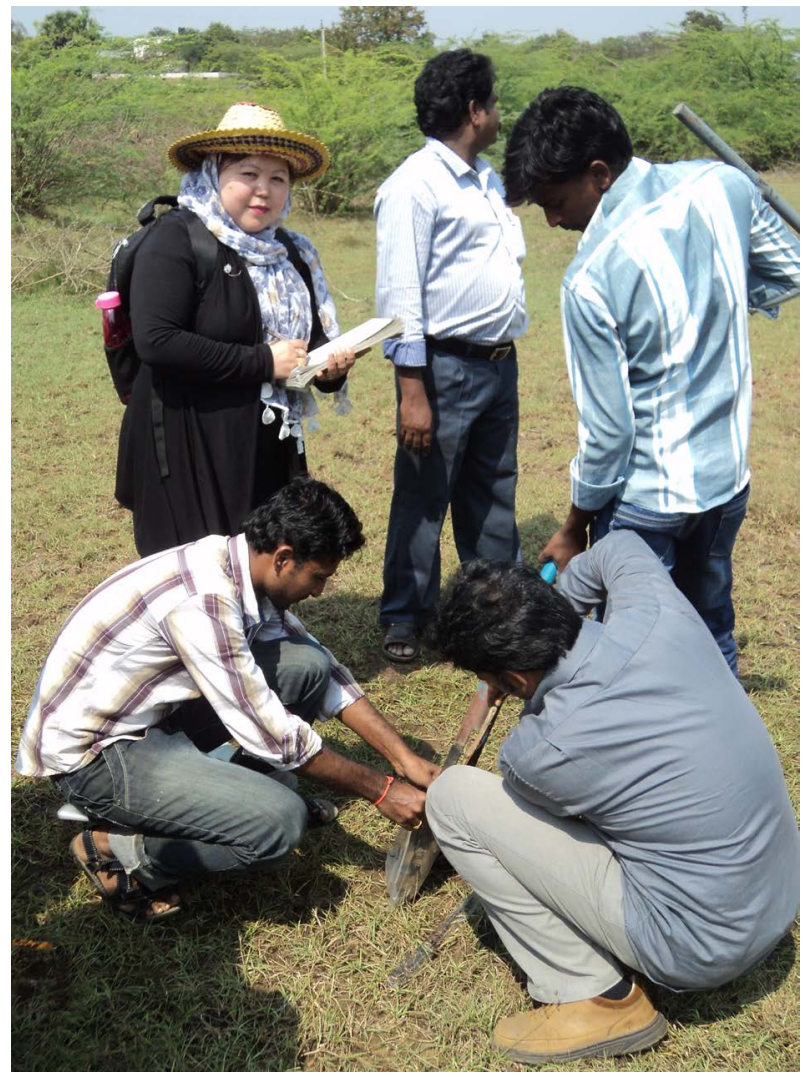

Photo 1. Collection of samples in paleo channel.

were weighed and their weight percentages were calculated. The heavies were mounted on a glass slide with Canada balsam. About 300 - 400 grains in each slide were identified and counted using the line method [33]. Study Method of geochemical factors was organic carbon, calcium and magnesium carbonate content were estimated in all selected sub-samples and examined its distribution in the core sediments.

\subsection{Results}

\subsubsection{Heavy Mineral}

According the lab analysis of samples, there is description and distribution pattern of individual Heavy minerals in different sediment's sample of paleo channel and flood plain. It is observed that the chief heavy minerals of the Gosthani river sands consist of garnets, sillimanite, opaque minerals, and Pyroxenes. The lesser abundant heavy minerals of desired area are amphiboles, zircon, monazite, rutile, staurolite, epidote. Present of these minerals in sediment of Gosthani River Estuary indicates the possibility of their derivation from such rock. The heavy minerals were derived from several distinct rock types. The availability of unstable minerals such garnet, kyanite, epidote, hornblende, staurolite, and opaque mineral in sediments also indicated erosion in the source area with rapid burial in the depositional basin [34]. Garnet, kyanite, epidote, staurolite and some sillimanite are suggestive of metamorphic provenance [35]. Present of rutile is 
characteristic of a provenance of metamorphosed argillaceous sediments of high grade schists [7]. Present of epidote indicates that part of sediments was derived from acid igneous and/or altered metamorphic rock. Opaque minerals are derived from crystalline rocks, both acidic and basic.

The salient features of these heavy minerals are described in the following:

\section{1) Garnet}

These are generally rounded and sub-rounded and occasionally sub-spherical. The two varieties observed are the almandine and grossularite. Almandine type is characterized by pink or purple red color and grossularite type by light honey yellow colour. Inclusions of iron oxides and zircons are observed occasionally. Both almandine and grossularite varieties occur mostly as fresh and unaltered grains (Figure 2).

\section{2) Sillimanite}

These grains are colorless and are either prismatic or acicular in shape. They show good relief and straight extinction. They have irregular terminations with no inclusions (Figure 2).

\section{3) Rutile}

Most of the grains are prismatic with pyramidal terminations. The grains exhibit reddish brown in color. They show high refractive index with thick borders. Hence the color of the grain is visible only in the middle of the grain, characterized by straight extinction (Figure 2).

\section{4) Zircon}

Zircon is colorless and usually oval. Prismatic grains with pyramidal terminations are also observed. Zoning is a characteristic feature of these grains (Figure 2).

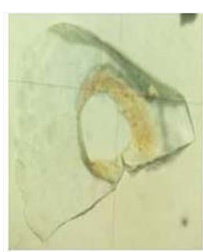

Garnet

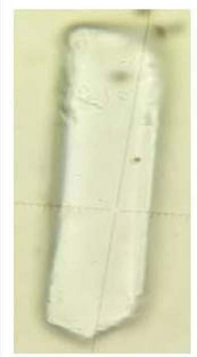

Siliminite
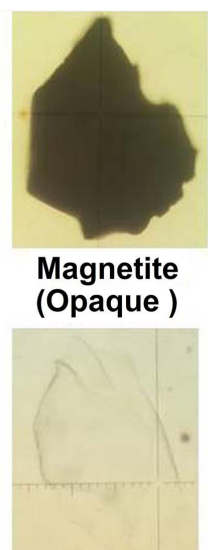

Muscovite

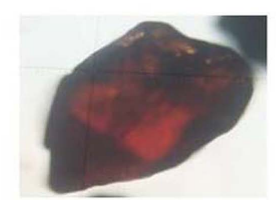

Rutile

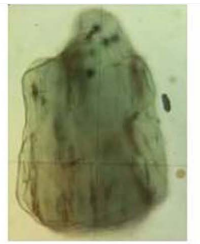

Amphiboles (Hornblende)

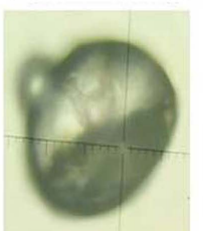

Monazite

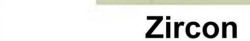

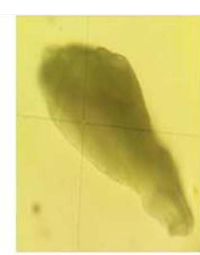

Pyroxene

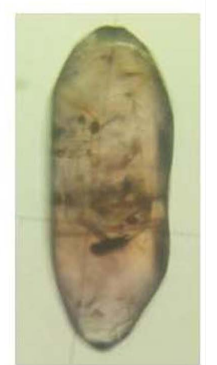

Zircon

Figure 2. Heavy minerals in the palaeo channel and flood plain samples under microscope. 


\subsubsection{Opaque Minerals}

These are present in a good proportion and are mostly rounded or sub-rounded. The opaques consist of magnetite and ilmenite, the ilmenite being dominant. It has been observed that a few grains show a dull grey luster in patches in reflected light indicating alteration of ilmenite to leucoxene (Figure 2).

\section{1) Monazite}

These are mostly rounded grains. Light yellow color is the characteristic property of this mineral. It shows high relief with distinct borders (Figure 2).

\section{2) Pyroxenes}

Hypersthene is the dominant mineral. It is characterized by short prismatic shape. The elongate to sturdy cleavage fragments. Often show inclusions. The pleochroism exhibited by hypersthene is strong from pink to green (Figure 2).

\section{3) Amphiboles}

Hornblende is the predominant mineral in the amphiboles. The green to greenish brown variety is the most common mineral. Grains are characterized by elongated form, platy cleavage and frayed ends. Hornblende grains exhibit uneven distribution of color, densest in the middle, becoming gradually paler towards the boundaries. Pleochroism is generally variable from strong to weak (Figure 2).

\section{4) Epidote}

It occurs mostly as sub-angular grains with relief. They show characteristic pistachio green color white some are colorless and exhibits oily appearance.

\section{5) Staurolite}

Staurolite is mostly sub-angular in outline and usually light yellow to straw yellow in color. Pleochroism is from straw to pale-yellow. Twinning is also present in some grains.

The result of lab analysis of surface and sub surface samples in Gosthani river estuary carried out that shows the heavies and light percentage of sediments (Table 1).

\subsection{Method of Study}

\section{Geochemical Characteristic}

\section{1) Estimation of Organic Carbon and Organic Matter}

Organic carbon is one of the most important content in the sediments [36] [37]. The organic carbon is determined by the process of titration between potassium dichromate and ferrous ammonium sulphate. This process is also called Walkey-Black's method [38] [39].

The Walkley-Black method provides an accurate estimate of soil organic carbon (SOC) with $100 \%$ recovery for most soil samples. The Walkley and Black method has been used as one of the standard methods to determine SOC [40], particularly in China [41]. For estimation of OC and OM as follows used the Walkey-Black's method. For the estimation of organic carbon, 0.5 gm of powdered sample is taken into a $500 \mathrm{ml}$ conical flask. To this, $10 \mathrm{ml}$ of a $1 \mathrm{~N}$ potassium dichromate is added. $20 \mathrm{ml}$ of concentrated $\mathrm{H}_{2} \mathrm{SO}_{4}$ is added to the above 
Table 1. Heavies and light percentage in palaeo channel and flood plain samples of gosthani river estuary.

\begin{tabular}{|c|c|c|c|c|c|c|}
\hline S. No & Sample & $\begin{array}{c}\text { Heavies } \\
\text { Wt }\end{array}$ & $\begin{array}{c}\text { Lights } \\
\mathrm{Wt}\end{array}$ & Total & $\begin{array}{c}\text { Heavies } \\
\text { Percentage }\end{array}$ & $\begin{array}{c}\text { Light } \\
\text { percentage }\end{array}$ \\
\hline 1 & PC3 & 1.63 & 13.62 & 15.25 & 10.69 & 89.31 \\
\hline 2 & PC4 & 1.21 & 13.91 & 15.12 & 8.00 & 92.00 \\
\hline 3 & PC5 & 2.09 & 19.95 & 22.04 & 9.48 & 90.52 \\
\hline 4 & PC6 & 1.15 & 13.5 & 14.65 & 7.85 & 92.15 \\
\hline 5 & PC7 & 1.97 & 12.89 & 14.86 & 13.26 & 86.74 \\
\hline 6 & PC8 & 0.73 & 14.3 & 15.03 & 4.86 & 95.14 \\
\hline 7 & PC9 & 1 & 13.2 & 14.2 & 7.04 & 92.96 \\
\hline 8 & PC10 & 1.65 & 12.23 & 13.88 & 11.89 & 88.11 \\
\hline 9 & PC11 & 1.08 & 13.55 & 14.63 & 7.38 & 962 \\
\hline 10 & PC3SS & 0.79 & 14.82 & 15.61 & 5.06 & 94.94 \\
\hline 11 & PC4SS & 0.42 & 14.51 & 14.93 & 2.81 & 97.19 \\
\hline 12 & PC5SS & 1.39 & 12.43 & 13.82 & 10.06 & 89.94 \\
\hline 13 & PC6SS & 0.93 & 10.66 & 11.59 & 8.02 & 91.98 \\
\hline 14 & PC7SS & 1.33 & 13.83 & 15.16 & 8.77 & 91.23 \\
\hline 15 & PC8SS & 1.06 & 14.83 & 15.89 & 6.67 & 93.33 \\
\hline 16 & PC9SS & 1.01 & 13.7 & 14.71 & 6.87 & 93.13 \\
\hline 17 & PC10SS & 1.17 & 13.92 & 15.09 & 7.75 & 92.25 \\
\hline 18 & PC11SS & 1.13 & 13.49 & 14.62 & 7.73 & 92.27 \\
\hline
\end{tabular}

solution and kept inside the solution for about 20 - 30 minutes. Then $170 \mathrm{ml}$ of distilled water is added to the solution, along with this $10 \mathrm{ml}$ of phosphoric acid, $0.2 \mathrm{gm}$ of sodium fluoride and 30 drops of di-phenyl amine indicator are added. The solution is titrated against $0.5 \mathrm{~N}$ ferrous ammonium sulphate which is taken in burette. The end point of the titration is brilliant green. This process is also carried out with blank, to estimate error.

Percentage of Total Organic Carbon $=(1-\mathrm{T} / \mathrm{S}) \times 10$

Where $\mathrm{S}=$ Blank Titration

$\mathrm{T}=$ Sample Titration

Percentage of Organic Matter $=1.724(1-\mathrm{T} / \mathrm{S}) \times 10$

1.724 is Marine Water

1.34 is Fresh Water

\section{2) Estimation of Carbonate and Bicarbonate}

0.4 gms of sediment sample is taken into a $100 \mathrm{ml}$ volumetric flask and $5 \mathrm{ml}$ of Acetic acid (25\%) is added to it and kept for $1-2 \mathrm{hrs}$. Then it is made up to 100 $\mathrm{ml}$ with distilled water and left overnight.

3) Estimation of $\mathrm{MgCO}_{3}$ and $\mathrm{CaCO}_{3}$ 
Pipette out $5 \mathrm{ml}$ of the above solution in a $50 \mathrm{ml}$ porcelain basin and $1 \mathrm{ml}$ of Trietanol amine along with $1 \mathrm{ml}$ of buffer solution is added to it. Dilute it with $10 \mathrm{ml}$ of distilled water and add a few drops of Eriochrome black T (EBT) indicator. It turns to rose red colour. Then it is titrated against $0.02 \mathrm{M}$ ethylenediaminetetraacetic acid (EDTA) solution until the colour changes to bluish green.

\section{4) Estimation of $\mathrm{CaCO}_{3}$}

Pipette out $5 \mathrm{ml}$ of the above solution in a $50 \mathrm{ml}$ porcelain basin and it is diluted with $10 \mathrm{ml}$ of distilled water. $2 \mathrm{ml}$ of Potassium hydroxide $\mathrm{KOH} \mathrm{(20 \% )} \mathrm{so-}$ lution and 5 drops of $\mathrm{P} \& \mathrm{R}$ indicator are added to the solution. It turns to wine red colour. Then it is titrated against $0.02 \mathrm{M}$ EDTA solution, untill blue colour is obtained.

$\%$ of $\mathrm{CaCO}_{3}$ in the given sediment $=\mathrm{EDTA}$ of $\mathrm{CaCO}_{3}$ solution value ${ }^{\star} 10$

$\%$ of $\mathrm{MgCO}_{3}$ in the given sediment $=\left(\mathrm{EDTA}\right.$ of $\mathrm{MgCO}_{3}$ and $\mathrm{CaCO}_{3}$ solution value-EDTA of $\mathrm{CaCO}_{3}$ solution value $) * 8.4$

$$
\begin{aligned}
\mathrm{Ca} \% & =\mathrm{CaCO}_{3} *(40 / 100) \\
\mathrm{Mg} \% & =\mathrm{MgCO}_{3}^{*}(24 / 84) \\
\mathrm{Ca} & =40 \\
\mathrm{CO}_{3} & =60 \\
& =100 \\
\mathrm{Mg} & =24 \\
\mathrm{CO}_{3} & =60 \\
& =84
\end{aligned}
$$

\section{Result}

\section{Geochemical Characteristic}

According to Walkey-Black's method, the OC and OM of samples of estuary bar, palaeo channel and flood plain determined. Lab analysis results shows there is exist a little amount of organic carbon and organic matter, but the amount of OM is more than OC in palaeo channel and flood plain environments (Table 2). Organic matter is very important in the movement of nutrients in the environment and plays a role in water retention on the surface of the planet. In addition organic matter in sediments indicates the residue of organic life, and is based on the geological sense, a fossil. An exception to this rule may be carbonaceous material produced in early Precambrian times by abiotic processes taking place before the first living cells came into existence. Organic carbon became more important and more abundant with the development and diversification of life. Calcium carbonate $\left(\mathrm{CaCO}_{3}\right)$ and magnesium carbonate $\left(\mathrm{MgCO}_{3}\right)$ are probably the most commonly known of all the carbonate minerals. From the study, found vary concentration of $\mathrm{MgCO}_{3}$ and $\mathrm{CaCO}_{3}$ in all part sediments of Gostany river estuary (Table 3). Carbonation of magnesium and calcium silicates has emerged as an interesting option for long term storage of captured $\mathrm{CO}_{2}$. It is shown that magnesium carbonate is a more stable option than calcium carbonate for storing $\mathrm{CO}_{2}$. 
Table 2. Total organic carbon and organic matter in palaeo channel and flood plain sample of Gosthani River Estuary.

\begin{tabular}{cccc}
\hline S. No & Sample Name & OC & OM \\
\hline 1 & PC3 & 1.23 & 2.12 \\
2 & PC4 & 0.375 & 0.646 \\
3 & PC5 & 0.321 & 0.553 \\
4 & PC6 & 0.642 & 1.106 \\
5 & PC7 & 0.267 & 0.461 \\
6 & PC8 & 0.375 & 0.646 \\
7 & PC9 & 0.267 & 0.461 \\
8 & PC10 & 0.321 & 0.553 \\
9 & PC11 & 1.605 & 2.767 \\
10 & PC3SS & 1.177 & 2.029 \\
11 & PC4SS & 0.963 & 1.660 \\
12 & PC5SS & 1.07 & 1.844 \\
13 & PC6SS & 1.605 & 2.767 \\
14 & PC7SS & 0.588 & 1.014 \\
15 & PC8SS & 1.07 & 1.844 \\
16 & PC9SS & 0.535 & 0.922 \\
17 & PC10SS & 0.267 & 0.461 \\
18 & PC11SS & 2.086 & 3.596 \\
\hline
\end{tabular}

Table 3. Calcium carbonate and magnesium carbonate in estuary bar, palaeo channel and flood plain samples of Gosthani River Estuary.

\begin{tabular}{|c|c|c|c|}
\hline S. No & SAMPLE NUMBER & $\mathrm{CaCO}_{3}+\mathrm{MgCO}_{3}$ & $\mathrm{CaCO}_{3}$ \\
\hline 1 & E9 & 0.6 & 0.3 \\
\hline 2 & E10 & 0.4 & 0.2 \\
\hline 3 & E11 & 0.5 & 0.1 \\
\hline 4 & E12 & 0.4 & 0.3 \\
\hline 5 & E13 & 0.5 & 0.2 \\
\hline 6 & E14 & 0.5 & 0.3 \\
\hline 7 & E15 & 0.4 & 0.2 \\
\hline 8 & E16 & 0.4 & 0.2 \\
\hline 9 & PC3 & 0.5 & 0.2 \\
\hline 10 & $\mathrm{PC} 4$ & 0.8 & 0.3 \\
\hline 11 & PC5 & 0.4 & 0.2 \\
\hline 12 & PC6 & 0.6 & 0.2 \\
\hline 13 & PC7 & 0.4 & 0.1 \\
\hline 14 & PC8 & 0.3 & 0.1 \\
\hline 15 & PC9 & 0.5 & 0.3 \\
\hline 16 & PC10 & 0.4 & 0.2 \\
\hline 17 & PC11 & 0.5 & 0.3 \\
\hline 18 & PC3SS & 0.6 & 0.2 \\
\hline 19 & PC4SS & 0.7 & 0.3 \\
\hline 20 & PC5SS & 0.5 & 0.2 \\
\hline 21 & PC6SS & 0.5 & 0.3 \\
\hline 22 & PC7SS & 0.5 & 0.2 \\
\hline 23 & PC8SS & 0.3 & 0.2 \\
\hline 24 & PC9SS & 0.4 & 0.3 \\
\hline 25 & PC10SS & 0.5 & 0.3 \\
\hline 26 & PC11SS & 0.6 & 0.3 \\
\hline
\end{tabular}




\section{Discussion and Conclusions}

1) It is observed that the chief heavy minerals of the Gosthani river sands consist of garnets, sillimanite, opaque minerals, and pyroxenes. The lesser abundant heavy minerals of desired area are amphiboles, zircon, monazite, rutile, staurolite, epidote. Present of these minerals in sediment of Gosthani River Estuary indicates the possibility of their derivation from such rock.

2) Present of epidote indicates that parts of sediments were derived from acid igneous and/or altered metamorphic rock. Opaque minerals are derived from crystalline rocks, both acidic and basic.

3) The heavy minerals were derived from several distinct rock types. The availability of unstable minerals such garnet, kyanite, epidote, hornblende, staurolite, and opaque mineral in sediments also indicated erosion in the source area with rapid burial in the depositional basin. Garnet, kyanite, epidote, staurolite and some sillimanite are suggestive of metamorphic provenance. Present of rutile is characteristic of a provenance of metamorphosed argillaceous sediments of high grade schists.

4) It is clear from the above observation that some of sediments were derived from metamorphic source. Finally the Gosthani river estuary sediments were derived from metamorphic and crystalline igneous rocks.

5) The existence of heavy minerals in Gosthani river estuary indicates that the sediments were essentially derived from metamorphic provenance varying from medium to high grade and partly from crystalline igneous rocks.

6) The various characters of rutile and zircon suggest that each of these minerals has a multisource.

7) Well rounded monazites come from Eastern Ghats. This is based on the occurrence of monazite in pegmatite and charnockites of Eastern Ghats.

8) According to geochemical studies settling of organic matter is high in areas where deposition of fine grained sediment takes place. The existence of organic carbon is often a good index for deciphering depositional environment of estuary.

9) Lab analysis results show that there is a high amount of organic carbon and organic matter, but the amount of OM is more than $\mathrm{OC}$ in paleo channel and flood plain environments, whereas organic matter is very important in the movement of nutrients in the environment and plays a role in water retention on the surface of the planet.

10) From the study, it is found that concentration of $\mathrm{MgCO}_{3}$ and $\mathrm{CaCO}_{3}$ varies in all part sediments of Gosthani river estuary. Carbonation of magnesium and calcium silicates has emerged as an interesting option for long term storage of captured $\mathrm{CO}_{2}$. It is shown that magnesium carbonate is a more stable option than calcium carbonate for storing $\mathrm{CO}_{2}$.

\section{Acknowledgements}

I take this opportunity to express my deep sense of gratitude to Prof. M. Jagan- 
nadha Rao, Professor in the Department of Geology and Director of Delta Studies Institute (DSI), Andhra University Visakhapatnam for his valuable guidance, suggestion, and for constant encouragement also provide the sampling and laboratory facilities to carry out this work. I am grateful Prof. Shivanna and appreciate him for his valuable help and constant encouragement, in addition I am thankful of reviewers for constructive comments.

\section{References}

[1] Pritchard, D.W. (1967) What Is an Estuary: Physical View Point. In: Lauf, G.H., Ed., Estuaries, A.A.A.S. Publ. 83, Washington DC, Vol. 13, 3-5.

[2] Wolanski, E. (2007) Estuarine Ecohydrology. Elsevier, Amsterdam.

[3] McLusky, D.S. and Elliott, M. (2004) The Estuarine Ecosystem: Ecology, Threats and Management. Oxford University Press, New York. https://doi.org/10.1093/acprof:oso/9780198525080.001.0001

[4] Silva, S., Lowry, M., Macaya-Solis, C., Byatt, B. and Lucas, M.C. (2017) Can Navigation Locks Be Used to Help Migratory Fishes with Poor Swimming Performance Pass Tidal Barrages? A Test with Lampreys. Ecological Engineering, 102, 291-302. https://doi.org/10.1016/j.ecoleng.2017.02.027

[5] Pettijohn, F.J. (1975) Sedimentary Rocks. 3rd Edition, Harper and Row, New York, $628 \mathrm{p}$.

[6] Illing, V.C. (1916) The Oil Fields of Trinidad. Proceedings of the Geologists Association, 27, $115 \mathrm{p}$.

[7] Folk, R.L. (1980) The Provenance of Rutile. Journal of Sedimentary Research, 50, 485-488.

[8] Van Andel, T.H. (1959) Reflections of the Interpretation of Heavy Minerals Analysis. Journal of Sedimentary Research, 29, 163-173.

[9] Krynine, P.D. (1946) The Tourmaline Group in Sediments. The Journal of Geology, 54, 65-87. https://doi.org/10.1086/625323

[10] Pettijohn, F.J., Potter, P.E. and Sievert, R. (1972) Sand and Sandstone. Springer, New York, 618 p.

[11] Lindholm, R.C. (1987) A Practical Approach to Sedimentology. Allen and Unwin Inc., Crows Nest, New South Wales, 285 p.

https://doi.org/10.1007/978-94-011-7683-5

[12] Mortan, A.C. (1985) Heavy Minerals in Provenance of Arenites. Zuffa, G.G., Ed. D. Reidel Publishing Company, Dordrecht, 249-277.

https://doi.org/10.1007/978-94-017-2809-6_12

[13] Friedman, G.M. (1961) Distinction between Dune, Beach and River Sands from Textural Characters. Journal of Sedimentary Research, 31, 514-529.

[14] Hutton, C.O. (1950) Studies on Heavy Detrital Minerals. Bulletin of the Geological Society of America, 61, 635-716. https://doi.org/10.1130/0016-7606(1950)61[635:SOHDM]2.0.CO;2

[15] Ramdohr, P. (1980) The Ore Minerals and Their Intergrowths, Vol. 2. Pergamon, Press, New York.

[16] Woolsely, J.R., Henry, V.J. and Hunt, J.L. (1975) Back Shore Heavy Mineral Concentration on Sapelo Island. Georgia: Journal of Sedimentary Petrology, 45, 280-284. 
[17] Kulm, M.D. (1988) Potential Heavy Mineral and Metal Placers on the Oregon Continental Shelf. Marine Mining, 7, 361-395.

[18] Rubey, W.W. (1933) The Size Distribution of Heavy Minerals with in a Water Laid Sandstone. Journal of Sedimentary Petrology, 3, 3-29.

[19] Rittenhouse, G. (1943) The Transportation and Deposition of Heavy Minerals. Geological Society of America Bulletin, 54, 1725-1780. https://doi.org/10.1130/GSAB-54-1725

[20] Komar, P.D. and Wang, C. (1984) Processes of Selective Grain Transport and the Formation of Placers on Beaches. The Journal of Geology, 92, 637-655. https://doi.org/10.1086/628903

[21] Li, Z. and Komar, P.D. (1992) Longshore Grain Sorting and Beach Placer Formation Adjacent to the Columia River. Journal of Sedimentary Petrology, 62, 429-441.

[22] Jablonski, S.A., Mecray, E.L., Munson, J.M. and Blackwood, D.S. (2002) Geochemical Sediment Analysis Procedures. U.S. Geological Survey Open-File Report 02-371.

[23] Müller, P.J. and Suess, E. (1979) Productivity, Sedimentation Rate and Sedimentary Organic Matter in the Oceans I. Organic Carbon Preservation. Deep Sea Research Part A: Oceanographic Research Papers, 26, 1347-1362. https://doi.org/10.1016/0198-0149(79)90003-7

[24] Demaison, G.J. and Moore, G.T. (1980) Anoxic Environments and Oil Source Bed Genesis. AAPG Bulletin, 64, 1179-1209. https://doi.org/10.1016/0146-6380(80)90017-0

[25] Arther, M.A., Dean, W.E. and Stow, D.A.V. (1984) Models for the Deposition of Mesozoic-Cenozoic Fine Grained Organic Carbon-Rich Sediments. In: Stow, D.A.V. and Piper, D.J.W., Eds., The Deep Sea Fine Grained Sediments. Deep Water Processes and Facies, Special Publications-The Geological Society 15, London, 527-560. https://doi.org/10.1144/GSL.SP.1984.015.01.34

[26] Tissot, B.P. and Welte, D.H. (1978) Petroleum form Ation and Occurrence. Springer-Verlag, Berlin, 538. https://doi.org/10.1007/978-3-642-96446-6

[27] Tissot, B., Demaison, G., Masson, P., Delteil, J.R. and Combaz, A. (1980) Paleoenvironment and Petroleum Potential of Middle Cretaceous Black Shales in Atlantic Basins. AAPG Bulletin, 64, 2051-2063.

[28] Summerhayes, C.P. (1981) Organic Facies of Middle Cretaceous Black Shales in Deep North Atlantic. AAPG Bulletin, 65, 2364-2380.

[29] Ganesh, B., Naidu, A.G.S.S., Jagannadha Rao, M., Karuna Karudu, T. and Avatharam, P. (2013) Studies on Textural Characteristics of Sediments from Gosthani River Estuary-Bheemunipatnam, A.P., East Coast of India. Journal of Indian Geophysical Union, 17, 139-151.

[30] Archaeological Survey of India (2006) Indian Archaeology (2000-2001): A Review (PDF). Archaeological Survey of India, New Delhi, 2, 3.

[31] The Hindu (2012) Evidence of Buddhist Site Found.

[32] Krumbein, W.C. and Pettijohn, F.J. (1938) Manual of Sedimentary Petrography. D. Appleton Century, New York, 549 p.

[33] Galehouse, J.S. (1969) Counting Grain Mounts: Number Percentage vs. Number Frequency.

[34] Duarah, B.P., Das, P.K. and Goswami, D.C. (1998) Heavy Mineral Study from Modern Sediments of a Point Bar in the Puthimari River near Puthimari Village, Kamrup District, Assam. Journal of the Indian Academy of Geoscience, 41, 47-52.

[35] Chaudhri, R.S. and Gill, G.T.S. (1980) Heavy Mineral Assemblage of the Siwalik 
Group of Nepal Himalayas. Journal of the Geological Society, 22, 220-226.

[36] Sverdrup, H.U., Johnson, M.W. and Fleming, R.H. (1942) The Oceans, Their Physics, Chemistry and Biology. Prentice-Hall, New York, 1087 p.

[37] Trask, P.D. (1939) Organic Content of Recent Marine Sediments. In: Trask, P.D., Ed., Resent Marine Sediments, SEPM Society for Sedimentary Geology, Tulsa, 428-453.

[38] Page, N.J. and Jackson, E.D. (1967) Preliminary Report on Sulfide and Platinum-Group Minerals in the Chromites of the Stillwater Complex, Montana in Geological Survey Research. U.S. Geol. Survey Prof. Paper 575, D123-D126.

[39] Gaudette, H.E., Wilson, R.F., Tonar, L. and Polger, D.W. (1974) An Inexpensive Titration Method for the Determination of Organic Carbon in Recent Sediments. Journal of Sedimentary Petrology, 44, 249-253.

[40] Nelson, D.W., Sommers, L.E., Sparks, D., Page, A., Helmke, P., et al. (1996) Total Carbon, Organic Carbon, and Organic Matter. In: Methods of Soil Analysis Part 3 , Chemical Methods, Soil Science Society of America, American Society of Agronomy, 961-1010

[41] Zhang, W.J., Wang, X.J., Xu, M.G., Huang, S.M., Liu, H., et al. (2010) Soil Organic Carbon Dynamics under Long-Term Fertilizations in Arable Land of Northern China. Biogeosciences, 7, 409-425. https://doi.org/10.5194/bg-7-409-2010 